\title{
Receptor-mediated Catabolism of
}

\section{Low Density Lipoprotein in Man}

\section{QUANTITATION USING GLUCOSYLATED LOW DENSITY LIPOPROTEIN}

\author{
Y. ANTero Kesaniemi, Joseph L. Witztum, and Urs P. Steinbrecher, \\ Department of Medicine, Division of Metabolic Disease, University of \\ California, San Diego, School of Medicine, La Jolla, California 92093
}

A B S T R A C T Low density lipoprotein (LDL) catabolism occurs by LDL receptor-dependent and LDL receptor-independent pathways. We have shown previously that nonenzymatic glucosylation of LDL in the presence of cyanoborohydride irreversibly blocks the lysine residues of LDL. Glucosylated LDL (GLCLDL) was not degraded by the LDL receptor of fibroblasts, and its degradation by macrophages was similar to that of native LDL. This suggested that GLC-LDL should be a good tracer of LDL receptorindependent catabolism, and if combined with a tracer of total LDL catabolism, should enable one to calculate the extent of LDL receptor-dependent catabolism.

To determine the contribution of each pathway in man, we prepared ${ }^{125}$ I-GLC-LDL and ${ }^{131}$ I-control LDL and simultaneously determined the fractional catabolic rate (FCR) of each tracer in four subjects. In preliminary experiments, we showed that the conditions for glucosylation did not affect LDL turnover. In the four subjects, the FCR for total LDL catabolism ranged from 0.345 to $0.724 \mathrm{~d}^{-1}$ with a mean of $0.57 \pm 0.16 \mathrm{~d}^{-1}$. The FCR of GLC-LDL varied from 0.071 to $0.141 \mathrm{~d}^{-1}$ with a mean of $0.11 \pm 0.03 \mathrm{~d}^{-1}$. The latter is similar to the FCR reported for native LDL in subjects with homozygous familial hypercholesterolemia, supporting the interpretation that GLC-LDL traces only the receptor-independent pathway. Despite the wide range of total LDL catabolism in these subjects, LDL receptor-independent catabolism accounted for only $19.5-20.6 \%$ of total catabolism. In turn, LDL receptor-dependent catabolism accounted

Dr. Kesaniemi is a visiting scientist from the 2nd Department of Medicine, University of Helskinki, Finland. Dr. Steinbrecher is a Fellow of the Medical Research Council of Canada. Address all correspondence to Dr. Witztum.

Received for publication 2 September 1982 and in revised form 13 December 1982. for $80 \%$ of total clearance in each person. Furthermore, while the decay curve of LDL showed the usual biphasic pattern, the decay curve of GLC-LDL was monoexponential in each subject even when followed for as long as $48 \mathrm{~d}$. This suggests that LDL receptor activity is responsible for the biphasic nature of LDL decay.

These studies emphasize the central role of LDL receptor activity in normal LDL metabolism in man.

\section{INTRODUCTION}

Because low density lipoproteins (LDL) play a central role in the development of atherosclerosis, a detailed understanding of their catabolism is of particular importance. Clearance of LDL from plasma is mediated via a high affinity LDL receptor-dependent pathway as well as one or more LDL receptor-independent pathways (1-3). The receptor-mediated process involves the recognition of apolipoprotein (apo)'-B, the major protein of the LDL particle, by a high affinity receptor present on cell membranes in various tissues, including liver (1-4). The classic work of Goldstein and Brown (1) has shown that receptor-mediated endocytosis of LDL leads to an orderly series of biochemical events, which serve to maintain cellular cholesterol homeostasis. In the absence of LDL receptors, as in homozygous familial hypercholesterolemia (HFH) (1) and in the Watanabe heritable hyperlipidemic rabbit (3-5), fractional catabolic rates (FCR) of LDL are markedly decreased, plasma LDL levels are grossly

\footnotetext{
${ }^{1}$ Abbreviations used in this paper: apo, apolipoprotein; C, control (LDL); CHD, cyclohexanedione-modified (LDL); GLC, glucosylated (LDL); FCR, fractional catabolic rate; $\mathrm{HFH}$, homozygous familial hypercholesterolemia; U/P, urinary excretion rate of ${ }^{125} I$ and ${ }^{131} I$ radioactivity to the ${ }^{125} I$ and ${ }^{131} I$ radioactivity in plasma.
} 
elevated, and LDL apo-B production rates are increased (3-7). The increased synthesis and degradation of LDL apo-B, of necessity, occurs almost entirely via LDL receptor-independent pathways. It is precisely in this setting of a high LDL flux via nonreceptor pathways that severe and premature atherosclerosis is observed. Thus, it would be important to know the relative contribution to total LDL catabolism of the receptor-independent pathway in man.

We have previously demonstrated that incubation of LDL in the presence of glucose and cyanoborohydride results in irreversible glucosylation of lysine groups of LDL and permanently blocks the ability of LDL to interact with the LDL receptor of fibroblasts (8). We have also shown that the metabolism of glucosylated (GLC) LDL by mouse peritoneal macrophages that express very few high affinity receptors for native human LDL, is similar to that of native LDL $(8,9)$. This suggested that GLC-LDL might be useful for quantitating receptor-independent LDL catabolism in vivo. By combining such a measurement with simultaneous measurement of native LDL catabolism, receptor-dependent and receptor-independent, it is possible to calculate that portion of LDL catabolism accounted for by the LDL receptor pathway $(10,11)$. This report describes our initial results using this technique in normoglycemic human subjects.

\section{METHODS}

Subjects. All studies reported here were performed on subjects admitted to the Special Diagnostic and Treatment Unit (Metabolic Unit) of the Veterans Administration Medical Center, San Diego, CA. The clinical characteristics of the six individuals studied are presented in Table I. Two of the subjects had suffered myocardial infarction (No. 4 and 5) and one (No. 6) had undergone endarterectomy for carotid vascular disease. Routine clinical laboratory tests indicated that at time of study all were free of thyroid, hepatic, or renal dysfunction, and had normal fasting and 2 -h post- prandial glucose values. Table I also shows the plasma lipid and lipoprotein values for each of the subjects, based on multiple measurements while on a defined diet as described below. Subjects 1, 2, and 3 had normal plasma lipids, while the other three had mild hypertriglyceridemia consistent with phenotype IV. None of the subjects had followed a therapeutic diet or received hypolipidemic drug therapy for the 3 mo before the study period. Subjects 1 and 2 participated in the control turnover studies and subjects 3-6 participated in the GLC-LDL turnover studies. All patients gave informed consent for the investigations, which were approved by the Human Studies Committee of the University of California, San Diego.

The subjects were fed an isocaloric, weight-maintenance diet of mixed solid food and liquid formula (Hospital Diet Products, Organon Inc., Buena Park, CA). The diet contained $45 \%$ of calories as carbohydrate, $15 \%$ as protein, and $40 \%$ as fat with a polyunsaturated/saturated fat ratio of 0.2 . Cholesterol intake averaged $100-150 \mathrm{mg} / \mathrm{d}$. A detailed description of this diet has been previously published (12-13). Three liquid meals and one solid meal were given per day with appropriate vitamins and mineral supplementation. Each subject was weighed daily, and caloric intake adjusted to maintain constant body weight throughout the study period.

Preparation and iodination of $L D L$. After the subjects had been on the mixed solid food and liquid formula diet for 1-2 wk, plasmapheresis was carried out by collecting blood $(500 \mathrm{ml})$ in sterile, pyrogen-free plastic bags containing $500 \mathrm{mg}$ of the disodium salt of EDTA. Plasma was separated by centrifugation $\left(4^{\circ} \mathrm{C}\right)$ at $5,500 \mathrm{~g}$ for $5 \mathrm{~min}$, and cells were reinfused. Isolation of $\mathrm{LDL}(d=1.025-1.060 \mathrm{~g} / \mathrm{ml})$ was carried out according to the method of Lindgren et al. (14), by using sterile techniques as we previously described (13). Plasma was adjusted to $d=1.025 \mathrm{~g} / \mathrm{ml}$ with a $\mathrm{NaCl}-$ $\mathrm{NaBr}$ solution and centrifuged in a $60 \mathrm{Ti}$ rotor in an $\mathrm{L} 2-65 \mathrm{~B}$ preparative ultracentrifuge (Beckman Instruments, Inc., Palo Alto, CA) at $59,000 \mathrm{rpm}\left(15^{\circ} \mathrm{C}\right)$ for $18 \mathrm{~h}$. The infranate was adjusted to $d=1.060 \mathrm{~g} / \mathrm{ml}$ and subjected to further ultracentrifugation for $14 \mathrm{~h}$ in a $65 \mathrm{Ti}$ rotor at $64,000 \mathrm{rpm}$ $\left(15^{\circ} \mathrm{C}\right)$. A final ultracentrifugation was done in a $40.3 \mathrm{Ti}$ rotor at 39,000 for $24 \mathrm{~h}\left(15^{\circ} \mathrm{C}\right)$, after addition of an equal volume of a $\mathrm{NaCl}-\mathrm{NaBr}$ solution of $d=1.070 \mathrm{~g} / \mathrm{ml}$. The concentrated LDL was then dialyzed against $0.15 \mathrm{M} \mathrm{NaCl}$ containing 0.01\% EDTA, pH 7.4, (EDTA-saline). The LDL was divided into two equal portions and one was labeled with ${ }^{125} I$ and the other with ${ }^{131}$ I by the iodine monochloride

TABLE I

Clinical Data and Plasma Lipids

\begin{tabular}{|c|c|c|c|c|c|c|c|c|}
\hline Patient & Age & Sex & Weight & $\begin{array}{l}\text { Ideal } \\
\text { weight }\end{array}$ & $\begin{array}{l}\text { Clinical } \\
\text { diagnosis }\end{array}$ & $\begin{array}{c}\text { Total } \\
\text { cholesterol }\end{array}$ & $\begin{array}{c}\text { Total } \\
\text { triglycerides }\end{array}$ & $\begin{array}{l}\text { LDL } \\
\text { cholestero }\end{array}$ \\
\hline & $y r$ & & $\mathrm{~kg}$ & $\%$ & & & $m g / d l$ & \\
\hline 1 & 53 & M & 109 & 160 & Normal & $181 \pm 4$ & $148 \pm 8$ & $123 \pm 3$ \\
\hline 2 & 60 & $\mathbf{M}$ & 70 & 118 & Normal & $245 \pm 4$ & $203 \pm 16$ & $154 \pm 4$ \\
\hline 3 & 60 & $F$ & 69 & 115 & Normal & $219 \pm 3$ & $95 \pm 3$ & $142 \pm 3$ \\
\hline 4 & 60 & $\mathbf{M}$ & 106 & 148 & CHD & $267 \pm 4$ & $292 \pm 16$ & $138 \pm 9$ \\
\hline 5 & 53 & $\mathbf{M}$ & 131 & 182 & CHD & $192 \pm 3$ & $265 \pm 11$ & $108 \pm 4$ \\
\hline 6 & 48 & $\mathbf{M}$ & 105 & 142 & CVD & $228 \pm 7$ & $374 \pm 15$ & $79 \pm 6$ \\
\hline
\end{tabular}

- Averages of eight determinations (mean \pm SEM).

CHD, coronary heart disease; CVD, carotid vascular disease. 
method as modified by Bilheimer et al (15). Reactants were added so that the molar ratio of iodine to protein was $<1$. Free radioiodide was removed by extensive dialysis of the iodinated lipoprotein against EDTA-saline. The amount of free iodide after dialysis was determined by thin-layer chromatography as previously described (13) and averaged $0.08 \%$ of total radioactivity for control (C) LDL and $0.05 \%$ for GLC-LDL. Specific activities of the labeled LDL preparations ranged between 7.0 and $50 \mathrm{cpm} / \mathrm{ng}$. The degree of lipid labeling was determined in each iodinated lipoprotin as previously described (13) and averaged $2.5 \pm 1.3 \%$ for $\mathrm{C}$ LDL and $2.9 \pm 1.8 \%$ for GLC-LDL (mean \pm SD)

Glucosylation of $L D L$. Glucose reacts with epsilon amino groups of lysine to form a labile Schiff base intermediate, which can spontaneously dissociate, or rearrange to give a stable ketoamine adduct (Amadori reaction). Because the latter reaction is slow, addition of a reducing agent is required to produce a LDL in which greater than one-third of lysines are glucosylated (8). Addition of a reducing agent traps the Schiff base form, yielding a glucitol lysine adduct that is stable even when boiled in $6 \mathrm{~N} \mathrm{HCl} \mathrm{(8).} \mathrm{We} \mathrm{chose}$ sodium cyanoborohydride as the reducing agent because it reacts selectively with the aldimine linkage, and produces less unwanted modification of protein than sodium borohydride. With the following conditions, $>45 \%$ of the lysine residues of LDL are reproducibly derivatized. In a typical incubation, 18-26 mg of sterile iodinated LDL protein at a final concentration of $2.4-2.7 \mathrm{mg} / \mathrm{ml}$ was incubated under sterile conditions for $5 \mathrm{~d}$ at $37^{\circ} \mathrm{C}$ in phosphate-buffered saline (PBS), pH 7.4, containing $80 \mathrm{mM}$ glucose and $200 \mathrm{mM}$ cyanoborohydride. (The cyanoborohydride and glucose were added as fresh sterile solutions for each incubation). The C-LDL was incubated under identical conditions except for omission of glucose. At the end of incubation, both GLCLDL and C-LDL were exhaustively dialyzed for $18 \mathrm{~h}$ against EDTA-saline. Before incubation, a typical concentrated native LDL preparation contained $22 \mathrm{ng} / \mathrm{ml}$ of cyanide, and after incubation with glucose and cyanoborohydride and extensive dialysis, $0.8 \mu \mathrm{g}$ of cyanide was detectable per milliliter sample; this resulted in a total cyanide dose injection of $0.96 \mu \mathrm{g}$. After equilibration in the average person, this would result in whole blood levels $<1 \mathrm{ng} / \mathrm{ml}$, which is below the range detected in whole blood in normal individuals $(0$ $150 \mathrm{ng} / \mathrm{ml}$; SmithKline Corp., SmithKline Clinical Laboratories, Burbank, CA).

Special control preparations. To exclude an effect on LDL metabolism due to the conditions needed for glucosylation, we prepared three control preparations: LDL incubated in PBS for $5 \mathrm{~d}$ at $37^{\circ} \mathrm{C}$ in the presence of cyanoborohydride (C-LDL); LDL incubated in PBS for $5 \mathrm{~d}$ at $37^{\circ} \mathrm{C}$ in the absence of cyanoborohydride (LDL- $37^{\circ} \mathrm{C}$, no borohydride); and to exclude an effect due to incubation at $37^{\circ} \mathrm{C}$, LDL incubated in PBS for $5 \mathrm{~d}$ at $4^{\circ} \mathrm{C}$ in the absence of cyanoborohydride (LDL $-4^{\circ} \mathrm{C}$, no borohydride). The metabolism of these three controls was compared in cell culture experiments and in vivo turnover studies described below.

Preparation of labeled $L D L$ for injection. After removal of glucose and cyanoborohydride by dialysis, the labeled LDL preparations were subjected to centrifugation at 20,000 $g$ for $30 \mathrm{~min}\left(4^{\circ} \mathrm{C}\right)$, the supernatant was then removed and passed through a $0.22-\mu \mathrm{m}$ Millipore filter. Sterile human serum albumin in a $5 \%$ solution was added to the labeled LDL to dilute the original preparation 10 -fold (13). This solution was then passed again through a $0.22-\mu \mathrm{m}$ Millipore filter and aliquots set aside for bacterial and fungal culture and for pyrogen testing.

Study protocol and sample analysis. $12 \mathrm{~d}$ after plasma- pheresis, 2-8 $\mathrm{mg}$ of ${ }^{125}$ I-GLC-LDL and ${ }^{131}$ I-C-LDL protein (total dose $10-50 \mu \mathrm{Ci}$ ) was injected intravenously. (In subject 6 , the isotope assignment was reversed to demonstrate that the differences in decay were not due to isotopic effect). 10 $\mathrm{ml}$ blood samples were collected at $5,10,15,20,30$, and 60 min, and $3,6,9,12,24,36$, and $48 \mathrm{~h}$; and daily thereafter for $14 \mathrm{~d}$ in all subjects and for up to 21 and $48 \mathrm{~d}$ in two subjects. Determinations of total plasma radioactivity and total cholesterol and triglyceride concentrations were made on each sample. Lipoprotein quantitation was done biweekly during the study period on plasma obtained after a 12 -h fast. Urine specimens were collected in bottles containing an alkaline preservative (16) and were pooled during the following time intervals after the intravenous injection of labels " 0 time" to $1,1-3,3-6,6-12$, and $12-24 \mathrm{~h}$ and for every 24-h period thereafter. Values for urinary radioactivity were normalized to a constant creatinine excretion. All radioactivity was determined in a double channel model 5820 automatic gamma spectrometer (Packard Instrument Co., Downers Grove, IL). Plasma lipids and lipoproteins were determined as described in the Lipid Research Clinic Manual of Laboratory Operations (17) with a Technicon AutoAnalyzer Model II (Technicon Instruments Corp., Tarrytown, NY).

Stability of labeled lipoproteins in vivo. To demonstrate that the physical properties of the labels in plasma did not change after injection, we did the following experiments with plasma obtained $15 \mathrm{~min}$, and $1,4,7$, and $11 \mathrm{~d}$ after injection. Because whole plasma radioactivity was determined, it was important to document that the radiolabel remained protein-bound. Therefore, an aliquot of each sample was precipitated with $10 \%$ trichloroacetic acid (TCA); for all samples, $90 \pm 2 \%$ of ${ }^{125}$ I counts (GLC-LDL) and $89 \pm 6 \%$ of ${ }^{131}$ I counts (C-LDL) were TCA-insoluble. Plasma samples were also subjected to ultracentrifugation, and the 1.020 1.070 density range isolated; $91 \pm 6 \%$ of ${ }^{125} \mathrm{I}$ counts (GLCLDL) and $88 \pm 10 \%$ of ${ }^{131}$ I counts (C-LDL) were recoverable in the LDL density range. As previously reported, GLC-LDL has enhanced mobility when subjected to electrophoresis in agarose (8). To further document the in vivo stability of GLC-LDL, agarose gel electrophoresis was performed on plasma samples obtained up to $8 \mathrm{~d}$ after injection of ${ }^{125} \mathrm{I}$ GLC-LDL and ${ }^{131}$ I-C-LDL. In every case, all ${ }^{125}$ I plasma radioactivity retained electrophoretic mobility equal to that of the starting GLC-LDL preparation, and always greater than that of C-LDL. In summary, these studies suggest that nearly all plasma radioactivity remained associated with $\mathrm{C}$ LDL and GLC-LDL, respectively, during the course of the turnover studies and that glucosylation of LDL was not reversed.

Data analysis of turnover studies. The kinetic parameters for GLC-LDL and C-LDL turnover were calculated from the plasma decay curves by using curve-peeling methods originally described by Matthews (18) and later adapted to LDL turnover studies by Langer et al. (19). Plasma volume was calculated by dividing the injected dose of radioactivity by the extrapolated $y$-intercept of the plasma radioactivity curve. Independent measures of FCR were made by relating the daily urinary excretion rate of ${ }^{125} \mathrm{I}$ and ${ }^{131} \mathrm{I}$ radioactivity to the ${ }^{125} \mathrm{I}$ and ${ }^{131} \mathrm{I}$ radioactivity in plasma (U/P ratio) (16). $\mathrm{U} / \mathrm{P}$ ratios were calculated as previously described (13) by using the mean plasma radioactivity values of each $24-h$ period. The rate of synthesis for apo-LDL was calculated by using the following formula and was expressed as milligrams of apo-LDL synthesized per day (19): $S R=F C R \times P V$ $X$ apo-LDL concentration, where $S R$ is rate of synthesis and $\mathrm{PV}$ is plasma volume. The concentration of apo-LDL was 
calculated from the mean of four measured values of the ratio of LDL cholesterol to LDL protein and the multiple measurement of LDL cholesterol (17). LDL protein was determined by the method of Lowry et al. (20).

Tissue culture studies. In the present studies, we tested each pair of labeled GLC-LDL and C-LDL preparations in tissue culture to demonstrate that the degree of glucosylation of the GLC-LDL was sufficient to completely block degradation via the LDL receptor. The cell culture techniques used have been described in detail previously $(8,21)$. The special control preparations were also tested in fibroblasts to show that incubation at $37^{\circ} \mathrm{C}$ and/or treatment with cyanoborohydride did not affect degradation via the LDL receptor. In addition, to exclude an effect of these treatments on degradation by other pathways, LDL from patient No. 1 were also tested in J774 cells, a macrophage-like cell line (obtained from J. Unkeless, The Rockefeller University, New York). These cells were grown in minimal essential medium with $10 \%$ fetal calf serum, and were incubated with labeled LDL preparations for $5 \mathrm{~h}$; otherwise the techniques were the same as those used with the fibroblasts (8).

\section{RESULTS}

Cell culture studies. We have previously shown that with conditions used in these incubations, $45-60 \%$ of lysine residues of LDL are irreversibly glucosylated $(8,9)$. We, $(8)$ and others $(22)$ have shown that when more than one-third of lysine residues of LDL are blocked, LDL is no longer recognized by the LDL receptor. To document the effectiveness of glucosylation, the degradation of each GLC-LDL preparation was tested on normal human fibroblasts and compared with that of the corresponding C-LDL; in every case, saturable, high affinity degradation was completely

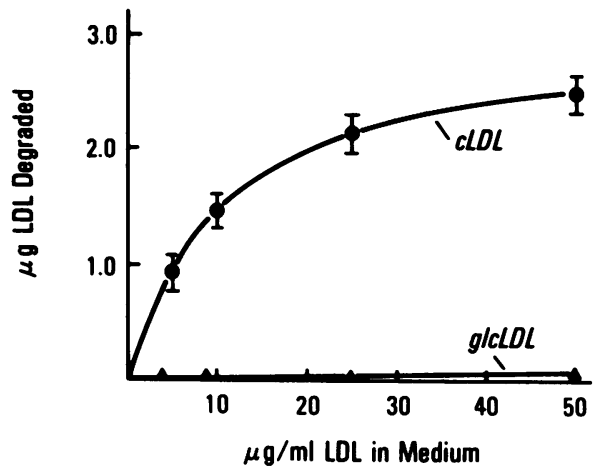

blocked for GLC-LDL, but was normal for C-LDL. Fig. 1 (left panel) shows the degradation of C-LDL and GLC-LDL vs. LDL concentration for the labeled preparations of subject 6; virtually identical results were found for each of the other subjects.

The results with the "special control" preparations indicated that in fibroblasts the degradation of LDL was unaffected by cyanoborohydride treatment or incubation at $37^{\circ} \mathrm{C}$ in the absence of glucose. Fig. 1 (right panel) shows the degradation curve in fibroblasts comparing C-LDL with untreated LDL kept at $4^{\circ} \mathrm{C}$. Similar results were seen comparing C-LDL with LDL incubated at $37^{\circ} \mathrm{C}$ in PBS alone. In addition, control and native LDL were all metabolized equally by J774 macrophage cells (data not shown).

Lack of effect of cyanoborohydride and incubation on $C-L D L$ catabolism. To exclude an independent effect of cyanoborohydride treatment on the catabolism of LDL, we compared the turnover of ${ }^{125} \mathrm{I}-\mathrm{LDL}$ incubated for $5 \mathrm{~d}$ at $37^{\circ} \mathrm{C}$ in the presence of cyanoborohydride (C-LDL) with ${ }^{131}$ I-LDL incubated for 5 $\mathrm{d}$ at $37^{\circ} \mathrm{C}$ without cyanoborohydride $\left(\mathrm{LDL}-37^{\circ} \mathrm{C}\right.$, no borohydride). When these tracers were simultaneously injected into subject 1 , the FCR for the control LDL was $0.42 \mathrm{~d}^{-1}$ and for the LDL incubated in the absence of cyanoborohydride, $0.46 \mathrm{~d}^{-1}$ (Fig. 2A). To rule out any effect of the $5-\mathrm{d}$ incubation at $37^{\circ} \mathrm{C}$ on the catabolism of C-LDL, an iodinated LDL preparation kept at $4^{\circ} \mathrm{C}\left(\mathrm{LDL}-4^{\circ} \mathrm{C}\right.$, no borohydride) and C-LDL were injected simultaneously into subject 2 . The FCR for the LDL- $4^{\circ} \mathrm{C}$ was $0.57 \mathrm{~d}^{-1}$ and for the C-LDL, $0.52 \mathrm{~d}^{-1}$ (Fig. 2B).

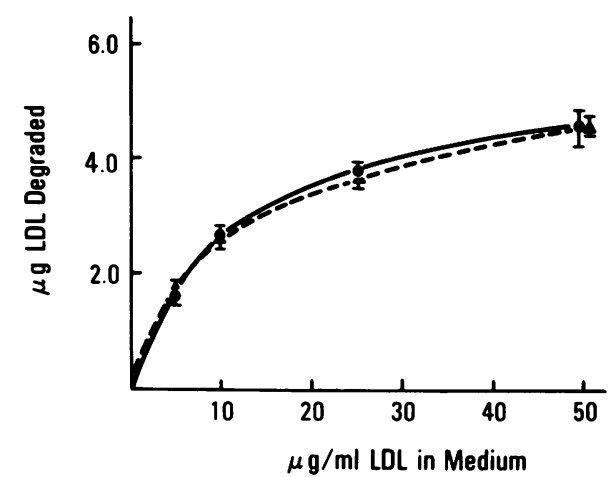

FiciURE 1 Degradation of various LDL preparations by human fibroblasts. $24 \mathrm{~h}$ before cells were exposed to labeled LDL preparations, medium was replaced with Dulbecco's modified Eagle's medium containing 5\% lipoprotein-deficient serum. After addition of indicated concentrations of labeled lipoprotein, cells were incubated overnight and then content of TCAsoluble, noniodide radioactivity was determined. Results are given as micrograms of LDL protein degraded per dish vs. micrograms of LDL added per milliliter of medium. Left panel; comparison of rates of degradation of C-LDL $(\bullet)$ and GLC-LDL $(\Delta)$ obtained from subject 6. Right panel; comparison of rates of degradation of C-LDL $(\bullet)$ and LDL-4 ${ }^{\circ} \mathrm{C}(\triangle)$ obtained from subject 2. C-LDL is LDL that was incubated for $5 \mathrm{~d}$ at $37^{\circ} \mathrm{C}$ in PBS in presence of cyanoborohydride, and LDL- $4^{\circ} \mathrm{C}$ is $\mathrm{LDL}$ that was simply kept at $4^{\circ} \mathrm{C}$ for the equivalent period
of time. 


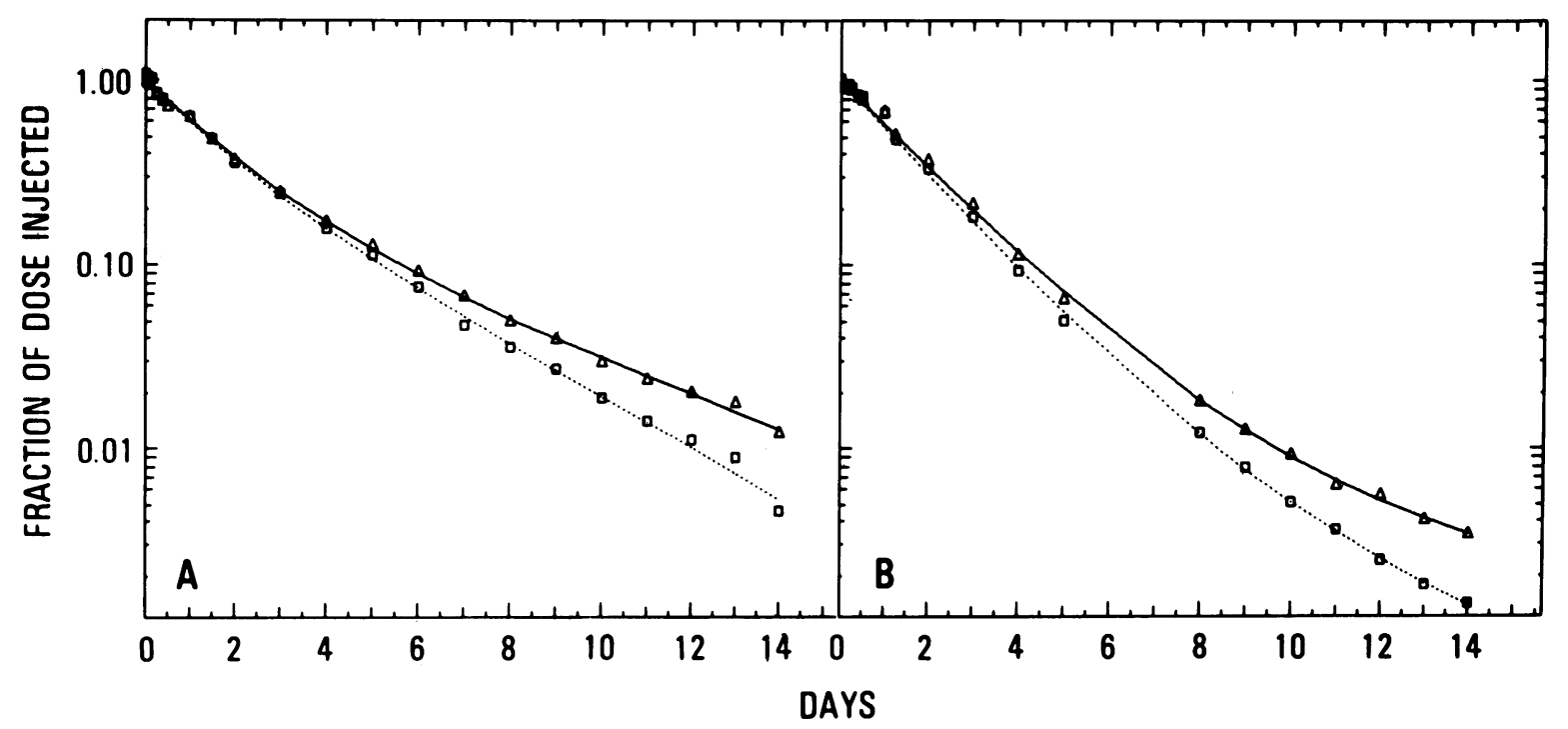

FIGURE 2 Comparison of turnover of C-LDL and native LDL in human subjects. A. LDL isolated from subject 1 was divided into two aliquots; one was labeled with ${ }^{125}$ I and then incubated for $5 \mathrm{~d}$ in PBS in presence of cyanoborohydride at $37^{\circ} \mathrm{C}$ (control $[\Delta]$ ). The other. portion was labeled with ${ }^{131} \mathrm{I}$, and then incubated for $5 \mathrm{~d}$ in PBS at $37^{\circ} \mathrm{C}$ in the absence of cyanoborohydride (LDL $-37^{\circ} \mathrm{C}$, no borohydride [ $\left.\square\right]$ ). Equal amounts of each label were injected simultaneously into subject 1 and the decay curve was determined. The FCR for C-LDL was 0.42 and for $L D L-37^{\circ} \mathrm{C}, 0.46 \mathrm{~d}^{-1}$. B. LDL isolated from subject 2 was divided into two aliquots. ${ }^{125} \mathrm{I}-\mathrm{LDL}$ was incubated in PBS in presence of cyanoborohydride for $5 \mathrm{~d}$ at $37^{\circ} \mathrm{C}$ (control $[\Delta]$ ), whereas an aliquot of ${ }^{131} \mathrm{I}-\mathrm{LDL}$ was simply kept for $5 \mathrm{~d}$ at $4^{\circ} \mathrm{C}\left(\mathrm{LDL}-4^{\circ} \mathrm{C}\right.$, no borohydride $[\square])$. Both labels were injected into subject 2. The FCR of C-LDL was 0.52 and for the LDL- $4^{\circ} \mathrm{C}, 0.57 \mathrm{~d}^{-1}$.

Catabolism of GLC-LDL and C-LDL. The catabolism of GLC-LDL was remarkably slower than that of C-LDL in each of the four subjects studied as shown in Fig. 3. The kinetic parameters for GLC-LDL and C-LDL turnover are shown in Table II. The FCR of C-LDL ranged from 0.345 to $0.724 \mathrm{~d}^{-1}$, while that for GLC-LDL ranged from 0.071 to $0.141 \mathrm{~d}^{-1}$ (mean $0.11 \pm 0,03)$. However, in all four subjects, the FCR of GLC-LDL as a percentage of that for C-LDL was remarkably constant, $19.5-20.6 \%$. When the $\mathrm{U} / \mathrm{P}$ ratio data were used to calculate the FCR of each tracer, GLC-LDL again accounted for only $20 \%$ or less of total LDL catabolism (Table II). The FCR for C-LDL derived from the $U / P$ ratios, however, must be qualified by the observation that the $U / P$ ratios were not constant over time, but showed an initial rise and subsequent slow decline with time (Fig. 4). Others (23, 24) have described a similar finding for the turnover of native LDL. In contrast, after $2 \mathrm{~d}$, the $\mathrm{U} / \mathrm{P}$ ratio for GLC-LDL was remarkably constant. Assuming GLC-LDL traces only the clearance of the receptorindependent pathway, it follows that the LDL receptor pathway accounted for $80 \%$ of total LDL clearance in each subject. In terms of absolute catabolic rates, receptor-mediated catabolism of LDL protein ranged from 10.5 to $20.5 \mathrm{mg} / \mathrm{d}$ per $\mathrm{kg}$ among these four subjects, while receptor-independent catabolism ranged from 2.7 to $4.9 \mathrm{mg} / \mathrm{d}$ per $\mathrm{kg}$. Assuming that all LDL cholesterol is catabolized as a unit with LDL protein, it can be estimated that receptor-mediated clearance of LDL cholesterol ranged from 14.9 to $20.2 \mathrm{mg} / \mathrm{d}$ per kg (Table III).

In contrast with the two exponentials found in each decay curve of the control LDL, the die-away curve of GLC-LDL was monoexponential in each of the patients even when followed for $48 \mathrm{~d}$ after injection. The monoexponential decay was observed even during the first few hours after injection during which numerous separate measurements were made. Fig. 5 shows the decay of GLC-LDL during the first $6 \mathrm{~h}$ for subject 3 whose complete decay curve can be seen in Fig. 3C. The slow monoexponential decay was also reflected in the low and constant $\mathrm{U} / \mathrm{P}$ ratio noted in all subjects. The monoexponential decay of GLC-LDL cannot be explained by a different initial volume of distribution because the calculated plasma volumes were the same for both C-LDL and GLC-LDL tracers (Table II).

Accelerated catabolism of GLC-LDL in some subjects. Subsequent to the studies above, we had the opportunity to study an individual with hypothyroid- 


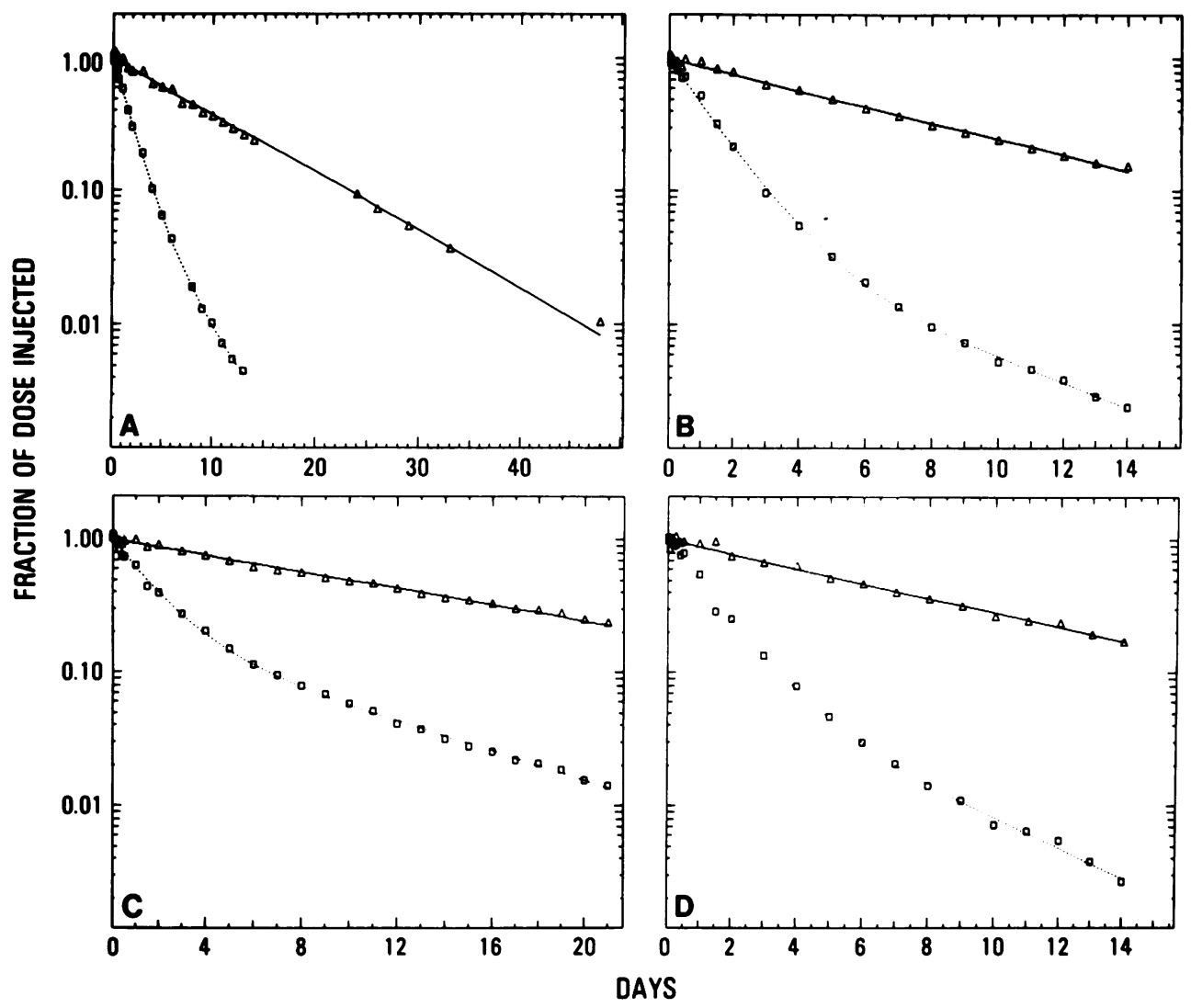

Figure 3 Turnover of C-LDL $(\square)$ and GLC-LDL $(\triangle)$ in human subjects. For each subject, an equal amount of ${ }^{125} \mathrm{I}-\mathrm{GLC}-\mathrm{LDL}$ and ${ }^{131} \mathrm{I}-\mathrm{C}-\mathrm{LDL}$ was injected simultaneously and plasma decay curves subsequently determined over the following 14-18 d (note different time scales for each subject). In subject 6 (D), the isotope assignment was reversed to rule out an isotope effect as etiology of the markedly different rates of decay. Kinetic parameters for each pair of turnovers can be found in Table II. A is for subject $4 ; B, 5 ; C, 3$; and D, 6 .

ism. Because hypothyroidism leads to a decreased expression of LDL receptors in vivo (25), we sought to measure the extent of the receptor-dependent path- way in this individual. The plasma decay curves for the control and GLC-LDL tracers in this subject are shown in Fig. 6. The control LDL showed the usual

TABLE II

Kinetic Parameters for C-LDL and GLC-LDL Turnover

\begin{tabular}{|c|c|c|c|c|c|c|c|c|c|c|c|c|c|}
\hline \multirow[b]{3}{*}{ Patient } & \multirow{2}{*}{\multicolumn{2}{|c|}{ Plasma volumet }} & \multirow[b]{3}{*}{$\begin{array}{c}\text { Plasma } \\
\text { apo-L.DI. }\end{array}$} & \multirow{3}{*}{$\begin{array}{c}\text { L.DL } \\
\text { protein/ } \\
\text { cholesterol } \\
\text { ratio }\end{array}$} & \multicolumn{6}{|c|}{ Apo-I.DI, fractional catalolic rate" } & \multirow{2}{*}{\multicolumn{3}{|c|}{ Apo-L.DL, absolute catabolic rate }} \\
\hline & & & & & \multicolumn{3}{|c|}{ From plasma decay } & \multicolumn{3}{|c|}{ From $U / P$ ratio } & & & \\
\hline & C-LDL & GLC:-LDH & & & GIC:-LDI. & C-LDL & $\begin{array}{c}\text { Glucosylated/ } \\
\text { control }\end{array}$ & GI.C-L.DL & C:-LDI & $\begin{array}{c}\text { Glucosylated/ } \\
\text { control }\end{array}$ & GIC:-LDI. & C-LDI. & $\begin{array}{l}\text { Receptor- } \\
\text { mediated }\end{array}$ \\
\hline & \multicolumn{2}{|r|}{$m l$} & $m g / d l$ & & \multicolumn{2}{|c|}{$d^{-1}$} & $\%$ & \multicolumn{2}{|c|}{$d^{-1}$} & $\%$ & \multicolumn{3}{|c|}{$m g / d$ per $k g$} \\
\hline 3 & 2876 & 2545 & 92 & 0.65 & 0.071 & 0.345 & 20.6 & 0.112 & 0.529 & 21.2 & 2.7 & 13.2 & 10.5 \\
\hline 4 & 3584 & 3490 & 134 & 0.97 & 0.108 & 0.552 & 19.6 & 0.087 & 0.665 & 13.1 & 4.9 & 25.0 & 20.1 \\
\hline 5 & 3764 & 3706 & 122 & 1.13 & 0.141 & 0.724 & 19.5 & 0.169 & 0.994 & 17.0 & 4.9 & 25.4 & 20.5 \\
\hline 6 & 3803 & 3449 & 77 & 0.98 & 0.127 & 0.648 & 19.6 & 0.104 & 0.661 & 15.7 & 3.5 & 18.1 & 14.6 \\
\hline
\end{tabular}

- Fraction of intravascular apo-LDL pool metabolized each day was calculated from the plasma die-away curve and from U/P ratio. † Plasma volume calculated separately for C-LDL and GLC-LDL by isotope dilution technique as described in Methods. 


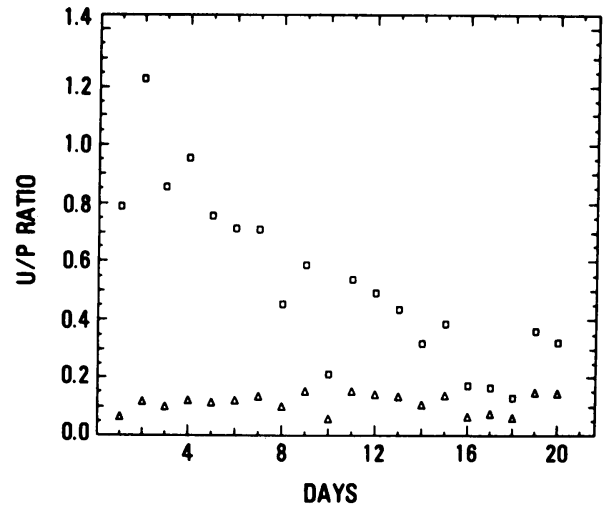

FiguRe $4 \mathrm{U} / \mathrm{P}$ ratio for ${ }^{125} \mathrm{I}$ radioactivity (GLC-LDL $[\Delta]$ ) and ${ }^{131}$ I radioactivity (C-LDL [ $\left.\square\right]$ ) obtained in subject 3 (turnover data given in Fig. $3 \mathrm{C}$ ). The $\mathrm{U} / \mathrm{P}$ ratio was determined as described in Methods. Note the low and rather flat $\mathrm{U} / \mathrm{P}$ ratio for GLC-LDL consistent with its slow, monoexponential decay from plasma.

biphasic decay pattern. However, after $4 \mathrm{~d}$ of monoexponential decay, there was the abrupt onset of a phase of rapid decay of the GLC-LDL tracer. We have subsequently seen a similar phenomenon in three of four diabetic subjects and in one other normoglycemic control. In each case, after 4-8 d of monoexponential decay, we noted the abrupt onset of a phase of rapid clearance of the GLC-LDL tracer, similar to that noted in Fig. 6.

\section{DISCUSSION}

LDL catabolism occurs by LDL receptor-dependent and LDL receptor-independent pathway(s). To estimate the extent of each pathway in vivo, Mahley et al. (10) and Shepherd et al. (11) introduced the concept of performing a double-labeled turnover study using native LDL as the tracer of total LDL catabolism and

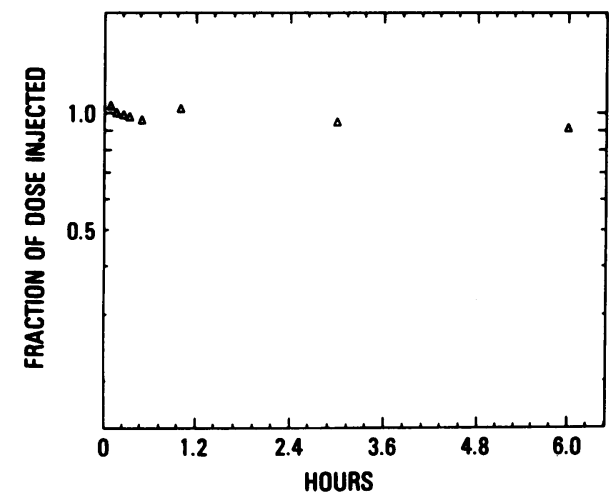

Figure 5 Plasma decay curve for GLC-LDL during the first $6 \mathrm{~h}$ after injection in subject 3 (Fig. 3C). Plasma radioactivity is expressed as fraction of dose injected.

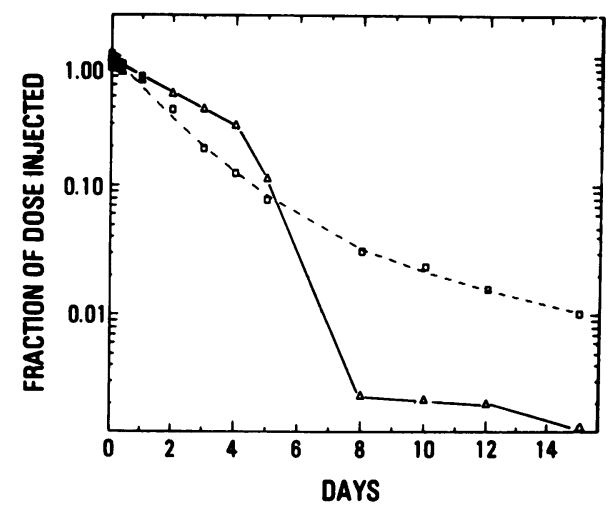

Figure 6 Plasma decay curves for C-LDL ( $\square)$ and GLCLDL $(\Delta)$ in a 42-yr-old man with mild hypothyroidism (thyroxine $=4.2 \mu \mathrm{g} / \mathrm{dl}$, thyroid-stimulating hormone $=69$ ). An equal amount of ${ }^{125}$ I-GLC-LDL and ${ }^{131}$ I-C-LDL was injected simultaneously and plasma decay curves determined. Note that although the first component of the GLC-LDL turnover was monoexponential, its rate of decay $($ FCR $=0.284$ ) was considerably faster than that of GLC-LDL in other subjects.

a chemically modified LDL as the tracer of receptorindependent catabolism. The difference in FCR between the two tracers is taken to reflect LDL catabolism occurring by the receptor-dependent pathway. For this technique to be valid, the chemically modified LDL must be irreversibly modified so that it is not recognized by the LDL receptor throughout the period of study. In addition, the modification of LDL must not interfere with clearance by any receptor-independent pathway(s).

Nonenzymatic glucosylation of LDL specifically blocks lysine groups of LDL (8) and presumably it is this modification that inhibits LDL recognition by the LDL receptor. We previously demonstrated that the conditions needed for glucosylation, as opposed to the covalent addition of glucose, did not affect LDL metabolism in cell culture or LDL turnover in guinea pigs (8). In the present study, we extend the prior obser-

TABLE III

Receptor-mediated and Receptor-independent Catabolism of LDL Cholesterol

\begin{tabular}{|c|c|c|c|c|}
\hline \multirow[b]{2}{*}{ Patient } & \multicolumn{3}{|c|}{ Alswolute clearance of I,DI, cholesterol } & \multirow[b]{2}{*}{$\begin{array}{c}\text { Receptor- } \\
\text { mediated/total }\end{array}$} \\
\hline & $\begin{array}{l}\text { Receptor- } \\
\text { merliated }\end{array}$ & $\begin{array}{l}\text { Receptor- } \\
\text { independent }\end{array}$ & Total & \\
\hline & & mig/d per kg & & $\%$ \\
\hline 3 & 16.2 & 4.2 & 20.4 & 79.4 \\
\hline 4 & 20.8 & 5.0 & 25.8 & 80.5 \\
\hline 5 & 18.1 & 4.4 & 22.5 & 80.4 \\
\hline 6 & 14.9 & 3.6 & 18.5 & 80.5 \\
\hline
\end{tabular}


vations to show that in man as well, the conditions for glucosylation do not have any significant effect on LDL turnover. Therefore, any difference in metabolic behavior between C-LDL and GLC-LDL is due to the derivatization of lysine by glucosylation.

Several lines of evidence suggest that GLC-LDL is an adequate tracer for the receptor-independent pathway. The modification is irreversible and total blockade of receptor-mediated degradation of GLC-LDL in fibroblast culture was verified for each injected GLC-LDL of the present study (Fig. 1). The observations that all plasma radioactivity originally used to label GLC-LDL retained enhanced electrophoretic mobility, the monoexponential decay of GLC-LDL for up to $48 \mathrm{~d}$, and a rather flat $U / P$ ratio all attest to the in vivo stability and persistent homogeneity of the GLC-LDL tracer.

Does glucosylation of LDL cause LDL to be uniquely recognized by any LDL receptor-independent pathway such as those that exist on macrophages? We have previously shown that degradation of GLC-LDL by macrophages is no different than that of native or CLDL (8) and the current observation that it has a slow monoexponential decay from plasma strengthens the suggestion that GLC-LDL has no enhanced clearance by any reticuloendothelial system. Finally, does glucosylation of LDL inhibit its in vivo clearance by any receptor-independent pathway(s)? Two lines of evidence suggest it does not. First, in the guinea pig, the clearance of GLC-LDL is identical to the clearance of methyl LDL (9). Second, and of particular relevance, we (9) have also shown that the turnover of GLC-LDL is similar to that of native LDL in the Watanabe heritable hyperlipidemic rabbit, an animal model for $\mathrm{HFH}$, which has $<5 \%$ of normal LDL receptors (3-5). In sum, our data suggest that GLC-LDL is an appropriate tracer for the receptor-independent pathway.

The FCR values for total LDL catabolism in our subjects ranged from 0.345 to $0.724 \mathrm{~d}^{-1}$. In a recent review (26) of 15 separate published reports of LDL turnover in normal subjects, we calculated a mean FCR of $0.371 \mathrm{~d}^{-1}$, which is similar to the value of 0.345 found for normolipidemic subject 3 . The FCR for subjects 4-6 were much higher, possibly reflecting their obesity and/or associated hypertriglyceridemia. We (27) and others (28) have reported that such subjects have LDL FCR values that range between 0.504 and $0.768 \mathrm{~d}^{-1}$. Despite the wide range of total LDL catabolism noted in the subjects of this report, it is remarkable that $\mathrm{LDL}$ receptor-dependent catabolism accounted for $\sim 80 \%$ of total LDL catabolism in each subject. This was true whether the receptor-dependent contribution was determined from the difference in the plasma die-away curves or as calculated from the
$\mathrm{U} / \mathrm{P}$ ratio data. These data are in agreement with the predictions of Goldstein and Brown (1) who estimated that at least two-thirds of LDL catabolism should occur by an LDL receptor-dependent process. Using GLCLDL (or methyl LDL) as the tracer of receptor-independent pathway, we found that $66-78 \%$ of LDL catabolism occurs by an LDL receptor-mediated pathway in the guinea pig $(8,9)$. Using GLC-LDL in the rabbit, we found that $75 \%$ of catabolism was receptormediated (9), which agrees with the value of $67 \%$ found by Bilheimer et al. (29) using methyl LDL, and $67 \%$ found by Pittman et al. (3) using still a third technique. These data in man and other species serve to emphasize the central importance of the LDL receptor for normal LDL metabolism.

The FCR for GLC-LDL ranged from 0.071 to 0.141 $\mathrm{d}^{-1}$ with a mean value of $0.112 \mathrm{~d}^{-1}$. These values are exactly in the range previously reported for LDL turnover of native LDL in patients with $\mathrm{HFH}$, (range of $\left.0.06-0.178 \mathrm{~d}^{-1}\right)(30-32)$. The similarity in values of FCR for GLC-LDL in our subjects and for native LDL in HFH subjects strongly supports the view that GLCLDL traces all of the receptor-independent pathways of LDL catabolism and only those pathways. In contrast, the FCR in normal subjects of cyclohexanedione (CHD)-modified LDL, which has also been used as a tracer of the receptor-independent pathway, has ranged from 0.163 to $0.261 \mathrm{~d}^{-1}(11,25-33)$, values higher than those for native LDL in HFH subjects. This suggests that CHD-LDL overestimates the receptor-independent pathway. In fact, using CHD-LDL, Shepherd et al. (11) and Thompson et al. (32) estimated that in man LDL receptor-dependent catabolism accounted for only $33-40 \%$ of total LDL catabolism. We found in the guinea pig that turnover of CHD-LDL is consistently greater than that of either GLC-LDL or methyl LDL (which are equal) (9) and Slater et al. (34) have reported that CHD-LDL is cleared more rapidly than methyl LDL in the rabbit (34). The reasons for the more rapid clearance of CHD-LDL are not clear but could be due to enhanced clearance of CHD-LDL by a nonreceptor mechanism (34), or to slow spontaneous reversal of the CHD modification, as first demonstrated by Mahley et al. (10) and confirmed by Slater et al. (34) and by us (9).

The decay curve for native LDL has an initial rapid phase of decay that lasts for 2-5 d, followed by a second, slower phase. The U/P data also suggest heterogeneity in the metabolism of LDL. In sharp contrast, the decay of GLC-LDL was monoexponential even when followed for as long as $48 \mathrm{~d}$. The exact explanation for this is unknown, but to our knowledge the only physiologic difference between the two tracers is the inability of GLC-LDL to interact with the LDL receptor. This suggests that the biphasic curve for na- 
tive LDL clearance is caused by reversible binding to readily accessible LDL receptors (as in liver, spleen, or endothelial cells) or that reversible exchange with an extravascular compartment occurs chiefly by an LDL receptor-dependent process.

Originally, we planned to study a larger number of subjects with this technique. However, in three of four diabetic patients, one hypothyroid subject, and one other normal control after several days of monoexponential decay, we noticed the abrupt onset of a phase of rapid clearance of GLC-LDL that began 4-10 d after injection. We are currently investigating this phenomenon and preliminary evidence suggests that it may be immunological in origin. In guinea pigs, nonenzymatic glucosylation of homologous LDL renders it immunogenic (35). Furthermore, in two of the human subjects, in whom the rapid decay was seen, (including the subject of Fig. 6) preliminary evidence suggests that antibodies against GLC-LDL, but not CLDL, were present in plasma obtained before injection of the tracers. However, in none of the subjects of the present report have such antibodies been found. Although we have noticed no adverse effects in any of our patients, we would urge caution in further in vivo studies with GLC-LDL until a better understanding of this phenomenon has been achieved.

\section{ACKNOWLEDGMENTS}

We thank Dr. Daniel Steinberg for his insightful advice and help and Dr. Scott Grundy for his continual support of these studies. We also express our deep thanks to Dr. Tom Carew and Dr. Bill Beltz for their advice in analysis and interpretation of the turnover data and to Jennifer Pattison, Lynne Lesh, Charles Maintainis, Lorna Joy, Richard L. Elam, and Milton Fisher for expert technical assistance. We thank the Nursing and Dietetic Services of the Veterans Administration Medical Center, San Diego, CA for their excellent help. We also thank Mrs. Sue Chrisman and Anita Fargo for expert secretarial assistance.

This work was supported by grant HL 14197 awarded by the National Heart, Lung, and Blood Institute.

\section{REFERENCES}

1. Goldstein, J. L., and M. S. Brown, 1977. Atherosclerosis: the low density lipoprotein receptor hypothesis. Metab. Clin. Exp. 26(11): 1257-1275.

2. Attie, A. D., R. C. Pittman, and D. Steinberg. 1982. Hepatic catabolism of low density lipoprotein: mechanisms and metabolic consequences. Hepatology (Baltimore). 2(2): 269-281.

3. Pittman, R. C., T. E. Carew, A. D. Attie, J. L. Witztum, Y. Watanabe, and D. Steinberg. 1982. Receptor-dependent and receptor-independent degradation of low density lipoprotein in normal rabbits and in receptor-deficient mutant rabbits. J. Biol. Chem. 257: 7994-8000.

4. Kita, T., M. S. Brown, Y. Watanabe, and J. L. Goldstein.
1981. Deficiency of low density lipoprotein receptors in liver and adrenal gland of the WHHL rabbit, an animal model of familial hypercholesterolemia. Proc. Natl. Acad. Sci. USA. 78: 2268-2272.

5. Tanzawa, K., Y. Shimada, M. Kuroda, Y. Tsujita, M. Arai, and Y. Watanabe. 1980. WHHL-rabbit: a low density lipoprotein receptor-deficient animal model for familial hypercholesterolemia. FEBS (Fed. Eur. Biochem. Soc.) Lett. 118(1): 81-84.

6. Brown, M., P. T. Kovanen, and J. L. Goldstein. 1981. Regulation of plasma cholesterol by lipoprotein receptors. Science (Wash. DC). 218: 628-635.

7. Simons, L. A., D. Reichl, N. B. Myant, and M. Mancini. 1975. The metabolism of the apoprotein of plasma low density lipoprotein in familial hyperbetalipoproteinemia in the homozygous form. Atherosclerosis. 21: 283-298.

8. Witztum, J. L., E. M. Mahoney, M. J. Branks, M. Fisher, R. Elam, and D. Steinberg. 1982. Nonenzymatic glucosylation of low density lipoprotein alters its biologic activity. Diabetes. 31: 283-291.

9. Steinbrecher, U. P., J. L. Witztum, Y. A. Kesaniemi, and R. L. Elam. 1983. Comparison of glucosylated low density lipoprotein with methylated or cyclohexanedionetreated low density lipoprotein in the measurement of receptor-independent low density lipoprotein catabolism. J. Clin. Invest. 71: 960-964.

10. Mahley, R. W., K. H. Weisgraber, G. W. Melchior, T. L. Innerarity, and K. S. Holcombe. 1980. Inhibition of receptor-mediated clearance of lysine and argininemodified lipoproteins from the plasma of rats and monkeys. Proc. Natl. Acad. Sci. USA. 77: 225-229.

11. Shepherd, J., S. Bicker, A. R. Lorimer, and C. J. Packard 1979. Receptor-mediated low density lipoprotein catabolism in man. J. Lipid Res. 20: 999-1006.

12. Grundy, S. M. 1975. Effects of polyunsaturated fats on lipid metabolism in patients with hypertriglyceridemia. J. Clin. Invest. 55: 269-282.

13. Kesaniemi, Y. A., and S. M. Grundy. 1982. Significance of low density lipoprotein production in the regulation of plasma cholesterol level in man. J. Clin. Invest. 70: 13-22.

14. Lindgren, F. T., L. C. Jensen, R. D. Wills, and N. K Freeman. 1969. Flotation rates, molecular weights and hydrated densities of low density lipoproteins. Lipids. 4: 337-344.

15. Bilheimer, D. W., J. L. Goldstein, S. M. Grundy, and M. S. Brown. 1975. Reduction in cholesterol and low density lipoprotein synthesis after portacaval shunt surgery in a patient with homozygous familial hypercholesterolemia. J. Clin. Invest. 56: 1420-1430.

16. Steinfeld, J. L., R. R. Paton, A. L. Flick, R. A. Milch F. E. Beach, and D. L. Tabern. 1957. Distribution and degradation of human serum albumin labeled with ${ }^{131}$ I by different techniques. Ann. NY Acad. Sci. 70: 109121.

17. Lipid Research Clinics Program Manual of Laboratory Operations. 1975. Government Printing Office, Washington, DC. Department of Health, Education, and Welfare Publication No. NIH 75-628.

18. Matthews, C. M. E. 1957. The theory of tracer experiments with iodine ${ }^{131}$-labeled plasma proteins. Phys. Med. Biol. 2: 36-53.

19. Langer, T., W. Stroberg, and R. I. Levy. 1972. The metabolism of low density lipoprotein in familial type II hyperlipoproteinemia. J. Clin. Invest. 51: 1528-1536. 
20. Lowry, O. H., N. J. Rosebrough, A. L. Farr, and R. J. Randall. 1951. Protein measurement with the Folin phenol reagent. J. Biol. Chem. 193: 265-275.

21. Drevon, C. A., A. D. Attie, S. H. Pangburn, and D. Steinberg. 1981. Metabolism of homologous and heterologous lipoproteins by cultured rat and human skin fibroblasts. J. Lipid Res. 22: 37-46.

22. Weisgraber, K. H., T. L. Innerarity, and R. W. Mahley. 1978. Role of the lysine residues of plasma lipoproteins in high affinity binding to cell surface receptors on human fibroblasts. J. Biol. Chem. 253: 9053-9062.

23. Turner, J. D., N.-A. Le, and W. V. Brown. 1981. Effect of changing dietary fat saturation on low density lipoprotein metabolism in man. Am. J. Physiol. 241: E57E63.

24. Goebel, R., M. Garnick, and M. Berman. 1976. A new model for low density apolipoprotein kinetics: evidence for two labeled moieties. Circulation. 54(Suppl 2): II-4.

25. Thompson, G. R., A. K. Soutar, F. A. Spengel, A. Jadhov, S. J. P. Gavigan, and N. B. Myant. 1981. Defects of receptor-mediated low density lipoprotein catabolism in homozygous familial cholesteolemia and hypothyroidism in vivo. Proc. Natl. Acad. Sci. USA. 78: 2591-2595.

26. Kesaniemi, A., G. L. Vega, and S. M. Grundy. 1982. Kinetics of apolipoprotein B in normal and hyperlipidemic man. In Lipoprotein Kinetics and Modeling. M. Berman, S. M. Grundy, B. V. Howard, editors Academic Press, Inc., New York. 181-205.

27. Kesaniemi, Y. A., and S. M. Grundy. 1982. Increased LDL production in association with obesity. Arteriosclerosis. 2: 421a. (Abstr.)

28. Ginsberg, H., N.-A. Le, J. Gibson, C. Mays, and W. V.
Brown. 1982. Effect of weight reduction on very low density lipoprotein and low density lipoprotein apoprotein-B metabolism. Clin. Res. 30: 393a. (Abstr.)

29. Bilheimer, D. W., Y. Watanabe, and T. Kita. 1982. Impaired receptor-mediated catabolism of low density lipoprotein in the WHHL rabbit, an animal model of familial hypercholesterolemia. Proc. Natl. Acad. Sci. USA. 79: 3305-3309.

30. Soutar, A. K., N. B. Myant, and G. R. Thompson. 1977. Simultaneous measurement of apolipoprotein B turnover in very low and low-density lipoproteins in familial hypercholesterolemia. Atherosclerosis. 28: 247-256.

31. Bilheimer, D. W., N. J. Stone, and S. M. Grundy. 1979. Metabolic studies in familial hypercholesterolemia. Evidence for a gene-dosage effect in vivo. J. Clin. Invest. 64: 524-533.

32. Thompson, G. R., and N. B. Myant. 1976. Low density lipoprotein turnover in familial hypercholesterolemia after plasma exchange. Atherosclerosis. 23: 371-377.

33. Ginsberg, H., I. Goldberg, P. Wang-Inverson, E. Gitter, N.-A. Le, H. Gilbert, and W. V. Brown. 1982. Increased non-receptor mediated low density lipoprotein catabolism in subjects with myeloproliferative diseases. Clin. Res. 30: 524a (Abstr.)

34. Slater, H. R., C. J. Packard, and J. Shepherd. 1982. Measurement of receptor-independent lipoprotein catabolism using 1,2 cyclohexanedione-modified low density lipoprotein. J. Lipid Res. 23: 92-96.

35. Witztum, J. L., U. P. Steinbrecher, M. Fisher, and Y. A. Kesaniemi. 1983. Nonenzymatic glucosylation of homologous LDL and albumin render them immunogenic in the guinea pig. Proc. Natl. Acad. Sci. USA. In press. 